\title{
Effects of Inoculants Producing Antifungal and Carboxylesterase Activities on Corn Silage and Its Shelf Life against Mold Contamination at Feed-Out Phase
}

\author{
Dimas Hand Vidya Paradhipta ${ }^{1,2}{ }^{\mathbb{D}}$, Young Ho Joo ${ }^{3}$, Hyuk Jun Lee ${ }^{1}$, Seong Shin Lee ${ }^{1}$, Hyeon Tak Noh ${ }^{1}$, \\ Jeong Seok Choi ${ }^{1}{ }^{(D}$, Jinwoo Kim ${ }^{4}{ }^{\mathbb{D}}$, Hyeong Gyu Min ${ }^{5}$ and Sam Churl Kim ${ }^{1, * \mathbb{C}}$ \\ 1 Division of Applied Life Science (BK21Four, Institute of Agriculture \& Life Science), Gyeongsang National \\ University, Jinju 52828, Korea; dimazhand@gmail.com (D.H.V.P.); hyukjun0209@gmail.com (H.J.L.); \\ seongshin73@gmail.com (S.S.L.); nht1647@gmail.com (H.T.N.); x47677104@gmail.com (J.S.C.) \\ 2 Faculty of Animal Science, Universitas Gadjah Mada, Yogyakarta 55281, Indonesia \\ 3 Institute of Agriculture and Life Science, Gyeongsang National University, Jinju 52828, Korea; \\ wn5886@gmail.com \\ 4 Department of Plant Medicine, Gyeongsang National University, Jinju 52828, Korea; jinwoo@gnu.ac.kr \\ 5 Agricultural Promotion Department, Sancheong Agricultural Technology Center, Sancheong 52221, Korea; \\ minhg@korea.kr \\ * Correspondence: kimsc@gnu.ac.kr; Tel.: +82-557721947; Fax: +82-557721949
}

\section{check for} updates

Citation: Paradhipta, D.H.V.; Joo, Y.H.; Lee, H.J.; Lee, S.S.; Noh, H.T.; Choi, J.S.; Kim, J.; Min, H.G.; Kim, S.C. Effects of Inoculants Producing Antifungal and Carboxylesterase Activities on Corn Silage and Its Shelf Life against Mold Contamination at Feed-Out Phase. Microorganisms 2021 9, 558. https://doi.org/10.3390/ microorganisms 9030558

Academic Editor: Haruki Kitazawa

Received: 8 February 2021

Accepted: 5 March 2021

Published: 8 March 2021

Publisher's Note: MDPI stays neutral with regard to jurisdictional claims in published maps and institutional affiliations.

Copyright: (c) 2021 by the authors. Licensee MDPI, Basel, Switzerland. This article is an open access article distributed under the terms and conditions of the Creative Commons Attribution (CC BY) license (https:// creativecommons.org/licenses/by/ $4.0 /)$.
Abstract: The present study aimed to investigate effects of dual-purpose inoculants (antifungal and carboxylesterase activities) not only on corn silage quality, but also its shelf life against mold contamination at feed-out phase. Corn forage was ensiled for $252 \mathrm{~d}$ with different inoculants of the following: control (CON), Lactobacillus brevis 5M2 (5M), Lactobacillus buchneri 6M1 (6M), and mixture of $5 \mathrm{M}$ and $6 \mathrm{M}$ at 1:1 ratio (MIX). After ensiling, corn silage was contaminated with Fusarium graminearum. Silages applied inoculants had positive effects by increased organic acid and lactic acid bacteria, and decreased undesirable microbes. At feed-out phase, contamination of F. graminearum into corn silage had a negative effect on aerobic stability caused by increased growth of undesirable microbes. However, silages applied inoculants had positive effects by decreased undesirable microbes and extended lactic acid bacteria and aerobic stability. Generally, MIX silage presented better effects on organic acid production, rumen degradation, inhibition of undesirable microbes, and aerobic stability than $5 \mathrm{M}$ silage and $6 \mathrm{M}$ silage. The present study concluded that application of inoculants into corn silage had positive effects on fermentation characteristics and extended shelf life against mold contamination at feed-out phase. A mixed inoculant appeared to have better effects of antifungal and carboxylesterase than a single inoculant.

Keywords: antifungal; carboxylesterase; corn silage; feed-out phase; Fusarium graminearum; Lactobacillus brevis 5M2; Lactobacillus buchneri 6M1

\section{Introduction}

Whole crop corn is the major cereal forage that often used as silage to supply the requirement of dietary fiber for both beef and dairy industries [1]. However, low fermentation quality and digestibility on corn silage can occur due to the contamination of undesirable microbes and lignification. In the last decade, many studies have been conducted to increase the quality of corn silage by applying microbial additives [2,3]. Previous researchers discovered that several species of lactic acid bacteria (LAB) could produce not only lactate, but also antifungal substances, which supported their roles as probiotics to improve animal health [4]. Additionally, the other studies reported that several species of LAB could release fibrolytic enzymes, such as carboxylesterase, which could improve the digestibility in the rumen [5]. Application of these LAB as silage inoculants have been proven to present 
antifungal effects by improving aerobic stability $[3,6,7]$ and carboxylesterase effect by increasing rumen digestibility $[3,8,9]$. Recently, the use of $\mathrm{LAB}$ as silage additive is strongly recommended by many previous studies [2,3,5-9] because LAB not only improves ensiling quality, but also potentially has a positive interaction with rumen microbes to increase rumen fermentation [5,8]. Moreover, Muck et al. [5] reviewed that the silage inoculated with LAB still presented beneficial effects as probiotic on ruminant performance and health.

In the viewpoint of field practice, contaminations of undesirable microbes such as yeast and mold on corn silage can occur in all steps of making silage consisting of preharvest, storage, and after fermentation/feed-out phases [10,11]. Keller et al. [12] reported that corn forage just before ensiling contained higher mycotoxins concentration than corn silage. It indicated that the contamination of undesirable microbes can be started in the field, such as rust infestation on the corn plant $[10,13]$. In addition, several factors during storage consisting of high temperature, low density, and broken silo can be the other causes for the increased contamination of undesirable microbes in the silage [11,14]. At feed-out phase, longer time of aerobic exposure decreases shelf life of silage. Commonly, in the small farm scale, baled silage can be exposed to the air for 3-5 d during feed-out. Mold mycotoxins infect silage aerobically and the damp weather can be a factor to accelerate its infection in the farm [15]. The environmental conditions of farm including humidity, temperature, and climate are uncontrolled factors and strongly influence the growth of mycotoxin molds that can affect shelf life of silage $[10,11]$. Besides environmental condition, contamination of mold on corn silage may occur when corn silage is mixed with other ingredients contaminating mycotoxins due to a poor management of feed storage. Silage study at preharvest and storage phase was conducted in many previous studies $[3,10,11]$. However, silage study at feed-out phase, especially against mold contamination, is in limited investigation.

In our previous study [16], Lactobacillus brevis 5M2 KACC 92268P and L. buchneri 6M1 KACC 92269P were screened from corn silage and selected based on their ability to present antifungal activity by inhibiting the growth of Fusarium graminearum and fibrolytic activity by producing carboxylesterase. However, the effects of these dual-purpose inoculants on shelf life of corn silage against mold contamination at feed out phase were not investigated yet. To demonstrate the mold contamination at feed-out phase, F. graminearum was applied into corn silage just after silo open in the present study. The F. graminearum are the most abundant mycotoxin mold of corn plants grown in South Korea [17]. It was hypothesized that antifungal activity of inoculant could extend shelf life of corn silage against mold contamination at feed-out phase, while carboxylesterase activity of inoculant could improve rumen degradation of corn silage. Therefore, the aim of present study determined effects of dual-purpose inoculants producing antifungal substances and carboxylesterase not only on chemical composition, fermentation characteristics, and rumen degradation of corn silage, but also its shelf life against the contamination of mold at feed-out phase.

\section{Materials and Methods}

\subsection{Inoculant Preparation}

Both LAB, consisting of L. brevis 5M2 KACC 92268P and L. buchneri 6M1 KACC 92269P, were grown in lactobacilli de Man Rogosa Sharpe media (MRS; Difco, Detroit, MI, USA) for $48 \mathrm{~h}$ in a $\mathrm{CO}_{2}$ incubator (Thermo Scientific, Waltham, MA, USA), and then diluted with sterile ultra-pure distilled water to reach the recommended application rate at $1 \times 105$ colony forming unit (cfu)/g according to several previous studies $[3,18,19]$.

\subsection{Silage Production}

Whole crop corn (Kwangpyeongok hybrid) was sown at 10 ha of a cornfield at Sancheong Agricultural Research and Extension Service, Sancheong, Gyeongnam province, South Korea (latitude $35^{\circ} 18^{\prime} \mathrm{N}$ and longitude $127^{\circ} 56^{\prime} \mathrm{E}$ ). Corn forage was harvested at $\frac{1}{2}$ milk line stage, and then chopped into 3-5 cm length using a Claas of Jaguar 850 corn harvester (Claas of America, Columbus, IN, USA). The chopped corn forage was ensiled into a 
$20 \mathrm{~L}$ mini silo $(8 \mathrm{~kg}$ ) for $252 \mathrm{~d}$ with different inoculants of the following: (i) no inoculant, applied distilled water at $80 \mu \mathrm{L} / \mathrm{g}$ of fresh forage (CON); (ii) L. brevis 5M2 KACC 92268P, applied at $1 \times 10^{5} \mathrm{cfu} / \mathrm{g}$ of fresh forage (5M); (iii) L. buchneri 6M1 KACC 92269P, applied at $1 \times 10^{5} \mathrm{cfu} / \mathrm{g}$ of fresh forage (6M); (iv) mixture of L. brevis 5M2 KACC 92268P and L. buchneri 6M1 KACC 92269P at 1:1 ratio, applied at $1 \times 10^{5} \mathrm{cfu} / \mathrm{g}$ of fresh forage (MIX). Each inoculant treatment, including CON silage, used four silos as replications. The distilled water and all inoculants were sprayed individually for each silo. During ensiling, all silos were stored at room temperature $\left(20 \pm 2{ }^{\circ} \mathrm{C}\right)$.

The fresh forage just before ensiling was subsampled from each silo, and then composited for each treatment at $500 \mathrm{~g}$. Furthermore, silages from 16 silos were also subsampled at $500 \mathrm{~g}$, respectively. The composited fresh forage and subsampled silage were used for analyses of chemical compositions and in vitro digestibility. To make silage extraction, $20 \mathrm{~g}$ of silage was subsampled from each silo and blended with sterile ultrapure water at $200 \mathrm{~mL}$ of during $30 \mathrm{~s}[16,20]$. The mixture of silage and ultrapure water was filtered through two layers of cheesecloth $[16,20]$. After filtering, the fresh silage extraction was used to analyze $\mathrm{pH}$ and microbial counts. For the further analyses of fermentation characteristics, silage extraction was stored at $-70{ }^{\circ} \mathrm{C}$ until. In addition, silage was subsampled at $2 \mathrm{~kg}$ and placed in aerobic condition to measure the aerobic stability.

\subsection{Chemical Compositions}

The subsampled forage and silage were placed into dry oven (OF-22GW, Jeio Tech, Seoul, South Korea) at $65^{\circ} \mathrm{C}$ for $48 \mathrm{~h}$. Then, samples were ground using a cutting mill (Shinmyung Electric Co., Ltd., Gimpo, South Korea) to pass 1-mm screen as a recommended size to measure chemical compositions and in vitro rumen digestibility. Samples at $10 \mathrm{~g}$ were dried in a forced-draft oven (OF-22GW, Jeio Tech, Seoul, South Korea) at $105{ }^{\circ} \mathrm{C}$ for $24 \mathrm{~h}$ (method 934.01 of AOAC [21]) to measure dry matter (DM). Crude ash (CA) was determined with a muffle furnace at $550{ }^{\circ} \mathrm{C}$ for $5 \mathrm{~h}$ (method 942.05 of AOAC [21]). Crude protein (CP) was measured by procedure of Kjeldahl (method 984.13 of AOAC [21]) through N analyzer (B-324, 412, 435 and 719 S Titrino, BUCHI, Flawil, Switzerland). On the other side, ether extract (EE) was determined by the producer of Soxhlet (method 920.39 of AOAC [21]). An Ankom ${ }^{200}$ Fiber Analyzer (Ankom Technology, Macedon, NY, USA) was used to analyze neutral detergent fiber (NDF; method 2002.04) and acid detergent fiber (ADF; method 973.13) according to protocol of AOAC [21]. The NDF was analyzed with heat stable amylase. Both NDF and ADF were expressed inclusive of residual ash. The difference concentration between NDF and ADF was determined as Hemicellulose (HEMI). The in vitro DM digestibility (IVDMD) was determined after incubating a dried sample (0.5 g) with rumen buffer for $48 \mathrm{~h}$ described by Tilley and Terry [22] using an Ankom Daisy ${ }^{\text {II }}$ (Ankom Technology, Macedon, NY, USA). Residue from the IVDMD assay was analyzed NDF to determine in vitro NDF digestibility (IVNDFD). Then, both the results of IVDMD and the IVNDFD were expressed as a percentage of DM (g/ $\mathrm{kg} \mathrm{DM})$.

\subsection{Fermentation Characteristics}

Silage $\mathrm{pH}$ was measured using a $\mathrm{pH}$ meter (SevenEasy, Mettler Toledo, Greifensee, Switzerland), while ammonia-N was determined by the colorimetric method following the protocol of Chaney and Marbach [23]. Before analyzing lactate and volatile fatty acid (VFA), the centrifugation of silage extraction at $5645 \times g$ for $15 \mathrm{~min}$ was conducted to collect the supernatant $[16,24]$. The supernatant was used to measure the concentrations of lactate and VFA using HPLC (L-2200, Hitachi, Tokyo, Japan) fitted with a UV detector (L-2400, Hitachi, Tokyo, Japan) and a column (Metacarb 87H, Varian, Palo Alto, CA, USA) following the method of Muck and Dickerson [25].

\subsection{Microbial Counts}

Fresh silage extract was continued into $10^{-2}-10^{-8}$ of dilution series to analyze microbial counts such as LAB, yeast, and mold. Different selective medium was prepared 
for each microbe. The LAB was grown at lactobacilli MRS agar media, while yeast and mold were grown at potato dextrose agar media (PDA; Difco, Detroit, MI, USA). The silage extract with different dilution series was plated in each selective agar medium with three replications, respectively. Furthermore, the $\mathrm{CO}_{2}$ incubator (Thermo Scientific, Waltham, MA, USA) was used to store MRS agar at $28^{\circ} \mathrm{C}$ for $48 \mathrm{~h} \mathrm{[16].} \mathrm{On} \mathrm{the} \mathrm{other} \mathrm{side,} \mathrm{aerobic}$ incubator (Johnsam Corp., Boocheon, South Korea) was used to store PDA plates at $28^{\circ} \mathrm{C}$ for $72 \mathrm{~h} \mathrm{[16].} \mathrm{Visible} \mathrm{colonies} \mathrm{from} \mathrm{each} \mathrm{plate} \mathrm{were} \mathrm{counted.} \mathrm{The} \mathrm{number} \mathrm{of} \mathrm{cfu} \mathrm{was}$ presented per gram of silage. The result of microbial data was transformed to $\log 10$.

\subsection{Rumen Degradation Kinetics and Fermentation Indices}

The animal care and procedure to maintain a cannulated heifer was approved by animal ethical committee of Gyeongsang National University, Jinju, South Korea (GNU191011-E0050). Before morning feeding, the rumen fluid ( $\mathrm{pH}$ 6.68) was collected and composited from two non-pregnant cannulated heifers. The diet of cannulated heifers consisted of rice straw and commercial concentrate mix at 8:2 ratio with addition of vitaminmineral premix. Furthermore, rumen fluid was filtered with two layers of cheesecloth to reduce remains diet in the fluid. Anaerobic culture medium was prepared according to previous study, and then mixed with rumen fluid at 1:2 ratio to make rumen buffer [26]. Dried sample at $0.5 \mathrm{~g}$ was prepared in an incubation bottle with $40 \mathrm{~mL}$ of rumen buffer. To reach anaerobic condition, the incubation bottle was gassed with $\mathrm{CO}_{2}$ and closed tightly with gas production sensor by $\mathrm{ANKOM}^{\mathrm{RF}}$ (Ankom Technology, Macedon, NY, USA). A total of 16 samples from each silo were incubated into 16 bottles along with two blanks. All incubation bottles were stored in an incubator at $39^{\circ} \mathrm{C}$ for $72 \mathrm{~h}$. Gas pressure was recorded in a computer at every $30 \mathrm{~min}$ also following the method of Adesogan et al. [26] to determine rumen degradation kinetics. At 10 psi of gas pressure in the incubation bottle, the sensor automatically opened the vent to release the gas. Calculation of rumen degradation kinetics used PROC NLIN of Statistical Analysis Software (SAS; Version 9. Cary, NC, USA) [27] to fit with the model of McDonald [28] following:

$$
\mathrm{Y}=\mathrm{A}+\mathrm{B}\left(1-\mathrm{e}^{-\mathrm{c}(\mathrm{t}-\mathrm{L})}\right) \text { for } \mathrm{t}>\mathrm{L}
$$

where $\mathrm{A}$ is the immediately degradable fraction; $\mathrm{B}$ is the potentially degradable fraction; $\mathrm{A}$ $+\mathrm{B}$ is the total degradable fraction; $\mathrm{C}$ is the fractional degradation rate; $\mathrm{L}$ is lag phase; $\mathrm{t}$ is time of incubation (h).

Each incubation bottle was opened after $72 \mathrm{~h}$ of incubation. The mixture of sample and rumen buffer from incubation bottle was transferred to $50 \mathrm{~mL}$ conical tube. Furthermore, the centrifugation at $2568 \times g$ for 15 min (Supra 21k, Hanil Electric Corporation, Seoul, South Korea, with rotor A50S-6C No.6) was conducted to separate remains sample and supernatant (rumen buffer). Both remains sample and supernatant were collected for further analyses. The supernatant was used to determine rumen fermentation indices consisting of $\mathrm{pH}$, ammonia-N, and VFA. The protocols to analyze $\mathrm{pH}, \mathrm{VFA}$, and ammonia-N were the same as described above.

\subsection{Microbial Changes and Aerobic Stability at Feed-Out Phase}

In aerobic condition, $1 \mathrm{~kg}$ of subsampled silage from each silo was placed in a box of polystyrene and stored for $120 \mathrm{~h}$ at room temperature $\left(22 \pm 2{ }^{\circ} \mathrm{C}\right)$. Two sensors of thermocouple (MORGAN TR-60CH, Hong Kong, China) were placed at the geometric center of each sample to record silage temperature. In the present study, temperature data of silage and room were collected every $30 \mathrm{~min}$. In principle, aerobic stability was measured by the time $(\mathrm{h})$ before a $2{ }^{\circ} \mathrm{C}$ increase in silage temperature above the ambient temperature [20]. The other $1 \mathrm{~kg}$ of subsampled silage from each silo was applied with F. graminearum head blight fungus MHGNU F312 at $1 \times 10^{5} \mathrm{cfu} / \mathrm{g}$ of fresh forage before measure the aerobic stability. The application rate of F. graminearum in the present study was conducted based on actual mold count of corn silages at a farm in our previous investigation [16]. Previously, F. graminearum head blight fungus MHGNU F312 was 
obtained through isolation procedure from the diseased corn plants. Before applied into corn silage, F. graminearum were grown in potato dextrose for $72 \mathrm{~h}$ in aerobe incubator (Johnsam Corp., Boocheon, South Korea), and then diluted with sterile ultra-pure distilled water to reach the recommended application rate. Generally, silages without F. graminearum application were labeled as 'without contamination', while silages with F. graminearum application were labeled as 'with contamination'. In this measurement, 32 polystyrene boxes were prepared to allocate silages without and with contaminations. All polystyrene boxes were stored in the same room condition. In addition, $50 \mathrm{~g}$ of silage from each polystyrene box were subsampled at $24,48,72,96$, and $120 \mathrm{~h}$ of aerobic exposure to measure the microbial counts. The protocol for counting LAB, yeast, and mold were the same as described above.

\subsection{Statistical Analysis}

All collected data in the present study were statistically analyzed as a completely randomized design by PROC GLM of SAS [27]. Its general model was $Y i j=\mu+T i+e i j$, where $Y_{i j}=$ response variable, $\mu=$ overall mean, $T i=$ the effect of inoculant, $e i j=$ error term For microbial counts at feed-out phase, data were statistically analyzed as a factorial design with a 4 (Inoculant; $\mathrm{CON}$ vs. $5 \mathrm{M}$ vs. $6 \mathrm{M}$ vs. MIX) $\times 2$ (Fusarium; without contamination vs. with contamination) $\times 6$ (aerobic hour; 0 vs. 24 vs. 48 vs. 72 vs. 96 vs. 120 h) arrangement by PROC MIX of SAS (SAS 2002). Its general model was $Y i j k l=\mu+\alpha i+\beta j+\gamma k+(\alpha \beta) i j+$ $\left(\alpha_{\gamma}\right) i k+\left(\beta_{\gamma}\right) i k+\left(\alpha \beta_{\gamma}\right) i j k+e i j k l$, where $Y i j k l=$ response variable, $\mu=$ overall mean, $\alpha i=$ the effect of inoculant, $\beta j=$ the effect of Fusarium, $y k=$ the effect of aerobic hour, $(\alpha \beta) i j=$ the interaction effect of inoculant and Fusarium, $(\alpha \gamma) i k=$ the interaction effect of inoculant and aerobic hour, $\left(\beta_{\mathrm{y}}\right) j k=$ the interaction effect of Fusarium and aerobic hour, $\left(\alpha \beta_{\mathrm{\gamma}}\right) i j k$ $=$ the interaction effect of inoculant, Fusarium, and aerobic hour, eijkl = error term. In addition, polynomial contrast through PROC GLM of SAS was used to investigate the linear or quadratic effect of aerobic hour on microbial counts at feed-out phase. Before testing a polynomial contrast for significance, the orthogonal coefficients for linear and quadratic contrasts were adjusted to account the spacing of aerobic hour $(0,24,48,72$, 96, and $120 \mathrm{~h}$ ) with PROC IML of SAS [27] For the aerobic stability, data was statistically analyzed as a factorial design with a 4 (Inoculant) $\times 2$ (Fusarium) arrangement by PROC MIXED of SAS [27]. Its general model was $Y i j k=\mu+\alpha i+\beta j+(\alpha \beta) i j+e i j k$, where $Y i j k=$ response variable, $\mu=$ overall mean, $\alpha i=$ the effect of inoculant, $\beta j=$ the effect of Fusarium, $(\alpha \beta) i j=$ the interaction effect of inoculant and Fusarium, eijk = error term. Mean separation was conducted by Tukey's test and the significant differences were declared at $p \leq 0.05$.

\section{Results}

\subsection{Chemical Compositions}

The concentrations of DM, CP, EE, CA, NDF, ADF, and HEMI from corn forage just before ensiling were $287,89.8,34.9,50.0,401,220$, and $186 \mathrm{~g} / \mathrm{kg}$, respectively (Table 1 ). In addition, IVDMD and IVNDFD of corn forage were 661 and $334 \mathrm{~g} / \mathrm{kg}$, respectively.

After ensiling, inoculant application did not affect the chemical compositions of corn silage (Table 2). The mean concentrations of DM, CP, EE, CA, NDF, ADF, and HEMI after ensiling were $266,88.3,32.8,51.2,413,227$, and $185 \mathrm{~g} / \mathrm{kg}$, respectively. However, the present study reported that 5M silage and MIX silage had higher IVDMD $(p=0.004 ; 695$ and $693 \mathrm{vs} .659 \mathrm{~g} / \mathrm{kg}$ ) and IVNDFD ( $p=0.006 ; 403$ and $393 \mathrm{vs} .347 \mathrm{~g} / \mathrm{kg}$ ) than those of CON silage, while 6M silage had no differences of IVDMD and IVNDFD among all silages. 
Table 1. The chemical composition of fresh forage before ensiling $(\mathrm{g} / \mathrm{kg}, \mathrm{DM})$.

\begin{tabular}{lcc}
\hline Item $^{\mathbf{1}}$ & Forage & SE \\
\hline Dry matter & 287 & 0.431 \\
Crude protein & 89.8 & 0.100 \\
Ether extract & 35.1 & 0.208 \\
Crude ash & 49.8 & 0.192 \\
Neutral detergent fiber & 404 & 1.070 \\
Acid detergent fiber & 219 & 0.902 \\
Hemicellulose & 186 & 1.884 \\
IVDMD & 661 & 2.058 \\
IVNDFD & 334 & 2.251 \\
\hline 1: IVDMD, in vitro dry matter digestibility; IVNDFD, in vitro neutral detergent fiber digestibility.
\end{tabular}

Table 2. Effects of dual-purpose inoculants on chemical compositions of corn silage ensiled for $252 \mathrm{~d}$ (g/ $\mathrm{kg}$, DM).

\begin{tabular}{|c|c|c|c|c|c|c|}
\hline \multirow{2}{*}{ Item $^{1}$} & \multicolumn{4}{|c|}{ Treatment $^{2}$} & \multirow{2}{*}{ SEM } & \multirow{2}{*}{$p$-Value } \\
\hline & $\mathrm{CON}$ & $5 \mathbf{M}$ & $6 \mathrm{M}$ & MIX & & \\
\hline Dry matter & 263 & 268 & 267 & 266 & 2.115 & 0.088 \\
\hline Crude protein & 87.9 & 88.5 & 88.5 & 88.2 & 1.451 & 0.948 \\
\hline Ether extract & 30.3 & 33.2 & 35.6 & 32.2 & 3.839 & 0.421 \\
\hline Crude ash & 51.8 & 49.8 & 50.5 & 52.7 & 4.410 & 0.812 \\
\hline Neutral detergent fiber & 415 & 416 & 406 & 418 & 13.57 & 0.881 \\
\hline Acid detergent fiber & 230 & 227 & 228 & 223 & 6.443 & 0.673 \\
\hline Hemicellulose & 185 & 189 & 180 & 185 & 13.32 & 0.840 \\
\hline IVDMD & $659^{b}$ & $695^{a}$ & $676^{a b}$ & $693^{a}$ & 6.620 & 0.004 \\
\hline IVNDFD & $347^{b}$ & $403^{a}$ & $375^{a b}$ & $393^{a}$ & 14.05 & 0.006 \\
\hline
\end{tabular}

a,b: Means in the same row with different superscripts differ significantly $(p<0.05) .{ }^{1}$ : IVDMD, in vitro dry matter digestibility; IVNDFD, in vitro neutral detergent fiber digestibility. ${ }^{2}$ : CON, corn silage applied without inoculant; $5 \mathrm{M}$, corn silage applied with Lactobacillus brevis 5M2; 6M, corn silage applied with Lactobacillus buchneri 6M1; MIX, corn silage applied with the mixture of L. brevis 5M2 and L. buchneri 6M1 at $1: 1$ ratio.

\subsection{Fermentation Characteristics and Microbial Counts}

The present study reported that all silages with inoculant applications had lower $\mathrm{pH}$ than CON silage after ensiled for $252 \mathrm{~d}(p=0.008 ; 3.68,3.68$, and 3.67 vs. 3.73; Table 3). The concentration of lactate was higher in $6 \mathrm{M}$ silage and MIX silage than in CON silage $(p=0.001 ; 100.1$ and 97.5 vs. $78.3 \mathrm{~g} / \mathrm{kg}$ ), while 5M silage was not different from CON silage. The highest acetate concentration was produced by MIX silage, followed by $5 \mathrm{M}$ silage and $6 \mathrm{M}$ silage, and then by CON silage $(p<0.001 ; 119.8$ vs. 77.3 and 87.3 vs. $49.7 \mathrm{~g} / \mathrm{kg}$ ). Inoculant application did not affect ammonia-N concentration of corn silage. In the present study, propionate and butyrate concentrations were not detected in all silages. The highest ratio of lactate to acetate was produced by CON silage, followed by 5M silage and $6 \mathrm{M}$ silage, and then by MIX silage ( $p<0.001 ; 1.58$ vs. 1.12 and 1.15 vs. 0.81$)$. On the other side, all silages with applied inoculants had higher LAB count $(p<0.001 ; 8.78,8.83$, and 8.77 vs. $7.81 \log 10 \mathrm{cfu} / \mathrm{g})$ with lower yeast count ( $p=0.012 ; 5.57,5.15$, and $5.18 \mathrm{vs}$. $5.57 \log 10 \mathrm{cfu} / \mathrm{g})$ and mold count $(p<0.001 ; 3.32,3.23$, and 3.21 vs. $3.68 \log 10 \mathrm{cfu} / \mathrm{g})$ than those of CON silage. 
Table 3. Effects of dual-purpose inoculants on fermentation characteristics and microbial count of corn silage ensiled for $252 \mathrm{~d}$.

\begin{tabular}{|c|c|c|c|c|c|c|}
\hline \multirow{2}{*}{ Item } & \multicolumn{4}{|c|}{ Treatment ${ }^{1}$} & \multirow{2}{*}{ SEM } & \multirow{2}{*}{$p$-Value } \\
\hline & $\mathrm{CON}$ & $5 \mathrm{M}$ & $6 \mathrm{M}$ & MIX & & \\
\hline \multicolumn{7}{|c|}{ Fermentation characteristics } \\
\hline $\mathrm{pH}$ & $3.73^{a}$ & $3.68^{b}$ & $3.68^{b}$ & $3.67^{\mathrm{b}}$ & 0.018 & 0.008 \\
\hline Ammonia-N, g/kg DM & 0.88 & 0.81 & 0.78 & 0.83 & 0.040 & 0.061 \\
\hline Lactate, $\mathrm{g} / \mathrm{kg} \mathrm{DM}$ & $78.3^{c}$ & $86.2^{b c}$ & $100.1^{\mathrm{a}}$ & $97.5^{\mathrm{a} b}$ & 4.798 & 0.001 \\
\hline Acetate, g/kg DM & $49.7^{c}$ & $77.3^{\mathrm{b}}$ & $87.3^{b}$ & $119.8^{a}$ & 12.15 & $<0.001$ \\
\hline Propionate, g/kg DM & $\mathrm{ND}^{2}$ & ND & ND & ND & $\mathrm{N} / \mathrm{A}$ & $\mathrm{N} / \mathrm{A}$ \\
\hline Butyrate, g/kg DM & ND & ND & ND & ND & $\mathrm{N} / \mathrm{A}$ & $\mathrm{N} / \mathrm{A}$ \\
\hline Lactate: acetate & $1.58^{\mathrm{a}}$ & $1.12^{b}$ & $1.15^{\mathrm{b}}$ & $0.81^{\mathrm{c}}$ & 0.065 & $<0.001$ \\
\hline \multicolumn{7}{|c|}{ Microbial count, $\log 10 \mathrm{cfu} / \mathrm{g}$} \\
\hline Lactic acid bacteria & $7.81^{b}$ & $8.78^{a}$ & $8.83^{a}$ & $8.77^{a}$ & 0.109 & $<0.001$ \\
\hline Yeast & $5.57^{\mathrm{a}}$ & $5.15^{b}$ & $5.18^{b}$ & $5.13^{b}$ & 0.164 & 0.012 \\
\hline Mold & $3.68^{a}$ & $3.32^{b}$ & $3.23^{b}$ & $3.21^{b}$ & 0.097 & $<0.001$ \\
\hline
\end{tabular}

${ }^{\mathrm{a}-\mathrm{c}}$ : Means in the same row with different superscripts differ significantly $(p<0.05) .{ }^{1}$ : CON, corn silage applied without inoculant; 5M, corn silage applied with Lactobacillus brevis 5M2; 6M, corn silage applied with Lactobacillus buchneri 6M1; MIX, corn silage applied with the mixture of L. brevis $5 \mathrm{M} 2$ and L. buchneri $6 \mathrm{M} 1$ at 1:1 ratio. ${ }^{2}$ : ND, not detected.

\subsection{Rumen Degradation Kinetics}

After $72 \mathrm{~h}$ of rumen incubation, MIX silage had lower immediately degradable fraction than other silages $(p<0.001 ; 0.69$ vs. $0.79,0.77$, and $0.78 \mathrm{~mL} / \mathrm{g}$; Table 4$)$. The potentially degradable fraction was higher in MIX silage than in CON silage and $5 \mathrm{M}$ silage $(p=0.007$; 4.33 vs. 3.77 and $3.92 \mathrm{~mL} / \mathrm{g}$ ), while $6 \mathrm{M}$ silage had no difference compared to others. Meanwhile, MIX silage had higher total degradable fraction than CON silage $(p=0.032$; 5.02 vs. $4.56 \mathrm{~mL} / \mathrm{g}$ ), while $5 \mathrm{M}$ silage and $6 \mathrm{M}$ silage had no difference compared to others. The MIX silage had higher lag phase than $5 \mathrm{M}$ silage and $6 \mathrm{M}$ silage $(p=0.016 ; 4.11$ vs. 3.39 and $3.17 \mathrm{~h}$ ), while $\mathrm{CON}$ silage had no difference compared to other silages. In addition, the fractional degradation rate was similar in all silages.

Table 4. Effects of dual-purpose inoculants on in vitro digestibility and degradation kinetics of corn silage incubated with rumen buffer for $72 \mathrm{~h}$.

\begin{tabular}{|c|c|c|c|c|c|c|}
\hline \multirow{2}{*}{ Item $^{1}$} & \multicolumn{4}{|c|}{ Treatment $^{2}$} & \multirow{2}{*}{ SEM } & \multirow{2}{*}{$p$-Value } \\
\hline & $\mathrm{CON}$ & $5 \mathrm{M}$ & $6 \mathrm{M}$ & MIX & & \\
\hline $\mathrm{A}, \mathrm{mL} / \mathrm{g} \mathrm{DM}$ & $0.79^{a}$ & $0.77^{a}$ & $0.78^{a}$ & $0.69^{b}$ & 0.012 & $<0.001$ \\
\hline $\mathrm{B}, \mathrm{mL} / \mathrm{g} \mathrm{DM}$ & $3.77^{\mathrm{b}}$ & $3.92^{b}$ & $4.05^{\mathrm{ab}}$ & $4.33^{\mathrm{a}}$ & 0.099 & 0.007 \\
\hline $\mathrm{A}+\mathrm{B}, \mathrm{mL} / \mathrm{g} \mathrm{DM}$ & $4.56^{\mathrm{b}}$ & $4.69^{a b}$ & $4.83^{a b}$ & $5.02^{\mathrm{a}}$ & 0.211 & 0.032 \\
\hline $\mathrm{C}, \% / \mathrm{h}$ & 0.14 & 0.13 & 0.12 & 0.12 & 0.007 & 0.206 \\
\hline $\mathrm{L}, \mathrm{h}$ & $3.58^{a b}$ & $3.39^{b}$ & $3.17^{b}$ & $4.11^{\mathrm{a}}$ & 0.230 & 0.016 \\
\hline
\end{tabular}

${ }^{\mathrm{a}, \mathrm{b}}$ : Means in the same row with different superscripts differ significantly $(p<0.05) .{ }^{1}: \mathrm{A}$, the immediately degradable fraction; $\mathrm{B}$, the potentially degradable fraction; $A+B$, the total degradable fraction; $C$, the fractional degradation rate; $L$, the lag phase. ${ }^{2}$ : CON, corn silage applied without inoculant; $5 \mathrm{M}$, corn silage applied with Lactobacillus brevis 5M2; 6M, corn silage applied with Lactobacillus buchneri 6M1; MIX, corn silage applied with the mixture of L. brevis 5M2 and L. buchneri 6M1 at 1:1 ratio.

\subsection{Rumen Fermentation Indices}

In rumen fermentation indices, $\mathrm{CON}$ silage had higher $\mathrm{pH}$ compared to the other silages ( $p=0.004 ; 6.32$ vs. $6.28,6.26,6.25$; Table 5$)$. However, MIX silage had higher total VFA concentration than other silages ( $p=0.001 ; 161.0$ vs. $138.6,143.0$, and $147.2 \mathrm{mM} / \mathrm{L}$ ). Propionate concentration was higher in CON silage than $6 \mathrm{M}$ silage and MIX silage ( $p=0.004$; 22.0 vs. 20.2 and $20.1 \%$ ), while $5 \mathrm{M}$ silage was not different compared to the other silages. Butyrate concentration was higher in MIX silage than in CON silage and $5 \mathrm{M}$ silage $(p=0.004$; 15.7 vs. 14.6 and $14.8 \%$ ), while $6 \mathrm{M}$ silage had similar concentration to other silages. The $5 \mathrm{M}$ silage had higher concentration of iso-valerate than CON silage ( $p=0.022 ; 3.20$ vs. $2.74 \%$ ), 
while $6 \mathrm{M}$ silage and MIX silage presented a similar concentration to other silages. Both $6 \mathrm{M}$ silage and MIX silage had higher acetate to propionate ratio than CON silage ( $p=0.009$; 2.90 and 2.91 vs. 2.63), while $5 \mathrm{M}$ silage had no difference compared to other silages. On the other side, inoculant application did not affect concentrations of ammonia-N and other VFA profiles.

Table 5. Effects of dual-purpose inoculants on rumen fermentation indices of corn silage incubated with rumen buffer for $72 \mathrm{~h}$.

\begin{tabular}{|c|c|c|c|c|c|c|}
\hline \multirow{2}{*}{ Item $^{1}$} & \multicolumn{4}{|c|}{ Treatment $^{2}$} & \multirow{2}{*}{ SEM } & \multirow{2}{*}{$p$-Value } \\
\hline & CON & $5 \mathrm{M}$ & $6 \mathrm{M}$ & MIX & & \\
\hline $\mathrm{pH}$ & $6.32^{a}$ & $6.28^{b}$ & $6.26^{b}$ & $6.25^{b}$ & 0.014 & 0.004 \\
\hline Ammonia-N, mg/dL & 35.0 & 35.2 & 34.3 & 33.4 & 1.310 & 0.318 \\
\hline Total VFA, mM/L & $138.6^{b}$ & $143.0^{\mathrm{b}}$ & $147.2^{b}$ & $161.0^{\mathrm{a}}$ & 4.668 & 0.001 \\
\hline Acetate, \% molar & 57.8 & 57.7 & 58.6 & 58.4 & 0.552 & 0.089 \\
\hline Propionate, \% molar & $22.0^{\mathrm{a}}$ & $21.3^{\mathrm{a}, \mathrm{b}}$ & $20.2^{b}$ & $20.1^{b}$ & 0.654 & 0.004 \\
\hline Iso-butyrate, $\%$ molar & 1.25 & 1.35 & 1.34 & 1.29 & 0.130 & 0.688 \\
\hline Butyrate, \% molar & $14.6^{b}$ & $14.8^{b}$ & $15.3^{\mathrm{a}, \mathrm{b}}$ & $15.7^{\mathrm{a}}$ & 0.337 & 0.004 \\
\hline Iso-valerate, \% molar & $2.74^{b}$ & $3.20^{\mathrm{a}}$ & $3.08^{a, b}$ & $3.03^{a}$ & 0.181 & 0.022 \\
\hline Valerate, \% molar & 1.56 & 1.63 & 1.49 & 1.44 & 0.221 & 0.629 \\
\hline Acetate: propionate & $2.63^{b}$ & $2.70^{\mathrm{a}, \mathrm{b}}$ & $2.90^{a}$ & $2.91^{\mathrm{a}}$ & 0.116 & 0.009 \\
\hline
\end{tabular}

a,b: Means in the same row with different superscripts differ significantly $(p<0.05) .{ }^{1}$ : VFA, volatile fatty acid. ${ }^{2}$ : CON, corn silage applied without inoculant; 5M, corn silage applied with Lactobacillus brevis 5M2; 6M, corn silage applied with Lactobacillus buchneri 6M1; MIX, corn silage applied with the mixture of L. brevis 5M2 and L. buchneri 6M1 at 1:1 ratio.

\subsection{Microbial Changes at Feed-Out Phase}

Both without and with contaminations, all silages with applied inoculants extended the growth of LAB by presenting higher $(p<0.05)$ count than CON silage from 24 to $96 \mathrm{~h}$ of aerobic exposure (Table 6). The 6M1 silage and MIX silage extended the growth of LAB by presenting higher $(p<0.05) \mathrm{LAB}$ count than the other silages at $120 \mathrm{~h}$ of aerobic exposure, both without and with contaminations. All silages with applied inoculants both without and with contaminations presented lower $(p<0.05)$ yeast count than CON silage from 24 to $96 \mathrm{~h}$ of aerobic exposure. The MIX silage without and with contaminations presented the lowest $(p<0.05)$ yeast count at $120 \mathrm{~h}$ of aerobic exposure. Supporting the result of yeast count, all silages with applied inoculants also had lower $(p<0.05)$ mold count than $\mathrm{CON}$ silage from 24 to $72 \mathrm{~h}$ in treatment without contamination, and from 24 to $48 \mathrm{~h}$ in treatment with contamination. Application of 6M silage and MIX silage had lower $(p<0.05)$ mold count than application of CON silage and $5 \mathrm{M}$ silage at $96 \mathrm{~h}$ in treatment without contamination and at $72 \mathrm{~h}$ in treatment with contamination. At $120 \mathrm{~h}$ of aerobic exposure, application of MIX silage without contamination presented the lowest $(p<0.05)$ mold count. In general, silages without contamination presented higher LAB count $(p<0.001)$ and lower counts of yeast $(p=0.007)$ and mold $(p<0.001)$ than silages with contamination, and the interaction effect $(p<0.001)$ between inoculant, mold, and aerobic hour were detected on all microbes. In addition, counts of yeast and mold increased linearly $(p<0.001)$ by increasing aerobic hour, while the LAB count decreased linearly $(p<0.001)$.

The mean count of all microbes was generated from 0 to $120 \mathrm{~h}$ of aerobic exposure. In silages without contamination, all silages with inoculant applications presented higher mean count of LAB during feed-out phase than CON silage $(p<0.05 ; 7.02,7.15$, and 7.24 vs. $5.78 \log 10 \mathrm{cfu} / \mathrm{g}$; Figure 1). Meanwhile, the lowest to the highest mean counts of yeast ( $p<0.05 ; 6.70$ vs. 6.80 vs. 7.02 vs. $7.40 \log 10 \mathrm{cfu} / \mathrm{g})$ and mold $(p<0.05 ; 5.56$ vs. 5.72 vs. 5.85 vs. $6.31 \log 10 \mathrm{cfu} / \mathrm{g}$ ) were produced by MIX silage, $6 \mathrm{M}$ silage, $5 \mathrm{M}$ silage, and $\mathrm{CON}$ silage, consecutively. In silages with contamination, all silages with applied inoculants also had higher mean count of LAB than CON silage $(p<0.05 ; 6.23,6.37$, and 6.32 vs. $5.50 \log 10 \mathrm{cfu} / \mathrm{g}$ ). Furthermore, mean counts of yeast and mold in silages with contamination had similar results in silage without contamination. Consecutively, MIX 
silage, $6 \mathrm{M}$ silage, $5 \mathrm{M}$ silage, and CON silage had the lowest to highest mean counts of yeast ( $p<0.05 ; 7.16$ vs. 7.23 vs. 7.39 vs. $7.65 \log 10 \mathrm{cfu} / \mathrm{g})$ and mold $(p<0.05 ; 6.07$ vs. 6.10 vs. 6.17 vs. $6.48 \log 10 \mathrm{cfu} / \mathrm{g})$.

Table 6. Effects of dual-purpose inoculants on microbial counts of corn silage without or with Fusarium contamination at feed-out phase $(\log 10 \mathrm{cfu} / \mathrm{g})$.

\begin{tabular}{|c|c|c|c|c|c|c|c|c|c|}
\hline \multirow{2}{*}{ Item } & \multicolumn{4}{|c|}{ Without Contamination 1} & \multicolumn{4}{|c|}{ With Contamination } & \multirow[t]{2}{*}{ SEM } \\
\hline & $\mathrm{CON}$ & $5 \mathrm{M}$ & $6 \mathrm{M}$ & MIX & CON & $5 \mathrm{M}$ & $6 \mathrm{M}$ & MIX & \\
\hline \multicolumn{10}{|l|}{ Lactic acid bacteria } \\
\hline $24 \mathrm{~h}$ & $7.19^{\mathrm{c}}$ & $8.04^{b}$ & $8.51^{\mathrm{a}}$ & $8.21^{b}$ & $7.11^{\mathrm{c}}$ & $7.83^{b}$ & $7.93^{b}$ & $7.97^{\mathrm{b}}$ & 0.103 \\
\hline $48 \mathrm{~h}$ & $6.23^{c}$ & $7.81^{\mathrm{a}}$ & $7.38^{b}$ & $8.02^{a}$ & $5.23^{\mathrm{d}}$ & $6.12^{\mathrm{c}}$ & $6.28^{c}$ & $6.28^{c}$ & 0.137 \\
\hline $72 \mathrm{~h}$ & $5.42^{b}$ & $8.17^{\mathrm{a}}$ & $8.50^{\mathrm{a}}$ & $8.35^{\mathrm{a}}$ & $4.74^{\mathrm{c}}$ & $5.41^{\mathrm{b}}$ & $5.52^{b}$ & $5.28^{b}$ & 0.168 \\
\hline $96 \mathrm{~h}$ & $4.16^{\mathrm{c}}$ & $5.11^{b}$ & $5.80^{\mathrm{a}}$ & $5.86^{\mathrm{a}}$ & $4.06^{\mathrm{c}}$ & $5.05^{b}$ & $5.52^{a b}$ & $5.28^{b}$ & 0.137 \\
\hline $120 \mathrm{~h}$ & $3.88^{c}$ & $4.19 \mathrm{bc}$ & $4.29^{b}$ & $4.68^{\mathrm{a}}$ & $4.04^{b c}$ & $4.21 \mathrm{bc}$ & $4.13^{\mathrm{bc}}$ & $4.36^{\mathrm{ab}}$ & 0.143 \\
\hline \multicolumn{10}{|l|}{ Yeast } \\
\hline $24 \mathrm{~h}$ & $5.55^{\mathrm{c}}$ & $5.19^{\mathrm{d}}$ & $5.19^{\mathrm{d}}$ & $5.10^{\mathrm{d}}$ & $6.25^{\mathrm{a}}$ & $5.81^{b}$ & $5.75^{\mathrm{bc}}$ & $5.58^{b c}$ & 0.094 \\
\hline $48 \mathrm{~h}$ & $6.91^{b}$ & $6.35^{\mathrm{d}}$ & $5.94^{\mathrm{e}}$ & $5.89^{\mathrm{e}}$ & $7.43^{a}$ & $7.37^{\mathrm{a}}$ & $6.77^{b c}$ & $6.67^{c}$ & 0.073 \\
\hline $72 \mathrm{~h}$ & $7.98^{b c}$ & $7.52^{\mathrm{d}}$ & $6.93^{e}$ & $6.96^{\mathrm{e}}$ & $8.29^{a}$ & $8.00^{b}$ & $7.80^{c}$ & $7.85^{b c}$ & 0.083 \\
\hline $96 \mathrm{~h}$ & $9.12^{\mathrm{a}}$ & $8.81^{b c}$ & $8.46^{\mathrm{cd}}$ & $8.36^{\mathrm{d}}$ & $9.17^{\mathrm{a}}$ & $8.90^{b}$ & $8.70^{b c}$ & $8.61^{\mathrm{c}}$ & 0.087 \\
\hline $120 \mathrm{~h}$ & $9.27^{\mathrm{a}}$ & $9.09^{\mathrm{a}}$ & $9.13^{a}$ & $8.76^{b}$ & $9.17^{\mathrm{a}}$ & $9.13^{\mathrm{a}}$ & $9.19^{a}$ & $9.14^{\mathrm{a}}$ & 0.058 \\
\hline \multicolumn{10}{|l|}{ Mold } \\
\hline $24 \mathrm{~h}$ & $3.74^{\mathrm{a}}$ & $3.27^{c}$ & $3.30 \mathrm{bc}$ & $3.25^{c}$ & $3.83^{\mathrm{a}}$ & $3.39 \mathrm{bc}$ & $3.49^{b}$ & $3.51^{b}$ & 0.093 \\
\hline $48 \mathrm{~h}$ & $4.92^{b}$ & $4.33^{c}$ & $4.38^{c}$ & $4.43^{c}$ & $5.52^{\mathrm{a}}$ & $5.02^{b}$ & $4.92^{b}$ & $5.03^{b}$ & 0.103 \\
\hline $72 \mathrm{~h}$ & $6.92^{b}$ & $6.04^{c}$ & $5.64^{\mathrm{d}}$ & $5.67^{\mathrm{d}}$ & $7.29^{a}$ & $7.04^{\mathrm{ab}}$ & $6.75^{b}$ & $6.76^{\mathrm{b}}$ & 0.124 \\
\hline $96 \mathrm{~h}$ & $9.14^{\mathrm{a}}$ & $8.97^{a b}$ & $8.50^{c}$ & $7.94^{\mathrm{d}}$ & $9.08^{a b}$ & $9.04^{\mathrm{ab}}$ & $8.92^{b}$ & $8.52^{c}$ & 0.089 \\
\hline $120 \mathrm{~h}$ & $9.43^{a}$ & $9.15^{\mathrm{a}}$ & $9.23^{\mathrm{a}}$ & $8.85^{b}$ & $9.43^{\mathrm{a}}$ & $9.23^{\mathrm{a}}$ & $9.30^{\mathrm{a}}$ & $9.36^{\mathrm{a}}$ & 0.120 \\
\hline Contrast $^{2}$ & & & \multicolumn{3}{|c|}{ Lactic acid bacteria } & \multicolumn{2}{|c|}{ Yeast } & \multicolumn{2}{|c|}{ Mold } \\
\hline INO & & & \multicolumn{3}{|c|}{$<0.001$} & \multicolumn{2}{|c|}{$<0.001$} & \multicolumn{2}{|c|}{$<0.001$} \\
\hline FUS & & & \multicolumn{3}{|c|}{$<0.001$} & \multicolumn{2}{|c|}{0.007} & \multicolumn{2}{|c|}{$<0.001$} \\
\hline HOUR & & & \multicolumn{3}{|c|}{$<0.001$} & \multicolumn{2}{|c|}{$<0.001$} & \multicolumn{2}{|c|}{0.001} \\
\hline INO*FUS & & & \multicolumn{3}{|c|}{$<0.001$} & \multicolumn{2}{|c|}{$<0.001$} & \multicolumn{2}{|c|}{0.001} \\
\hline INO*HOUR & & & \multicolumn{3}{|c|}{$<0.001$} & \multicolumn{2}{|c|}{$<0.001$} & \multicolumn{2}{|c|}{0.001} \\
\hline FUS*HOUR & & & \multicolumn{3}{|c|}{$<0.001$} & \multicolumn{2}{|c|}{$<0.001$} & \multicolumn{2}{|c|}{$<0.001$} \\
\hline INO*FUS*HOUR & & & \multicolumn{3}{|c|}{$<0.001$} & & & & \\
\hline HOUR linear & & & & $<0.001$ & & & & & \\
\hline HOUR quadratic & & & & 0.679 & & & & & \\
\hline
\end{tabular}

${ }^{a}-\mathrm{e}:$ Means in the same row with different superscripts differ significantly $(p<0.05) .{ }^{1}$ : Without contamination, corn silage without Fusarium graminearum contamination at silo open; with contamination, corn silage with $F$. graminearum contamination at silo open; $\mathrm{CON}$, corn silage applied without inoculant; $5 \mathrm{M}$, corn silage applied with Lactobacillus brevis 5M2; 6M, corn silage applied with Lactobacillus buchneri 6M1; MIX, corn silage applied with the mixture of L. brevis $5 \mathrm{M} 2$ and L. buchneri $6 \mathrm{M} 1$ at 1:1 ratio. ${ }^{2}$ : INO, inoculant effect; FUS, Fusarium effect; HOUR, aerobic hour effect; INO*FUS, interaction effect between inoculant and Fusarium; INO*HOUR, interaction effect between inoculant and aerobic hour; FUS*HOUR, interaction effect between Fusarium and aerobic hour; INO*FUS*HOUR, interaction effect between inoculant, Fusarium, and aerobic hour.

\subsection{Aerobic Stability}

Generally, silages with contamination had lower aerobic stability than silages without contamination ( $p<0.001 ; 42.8$ vs. 53.1 h; Figure 2 ). The highest aerobic stability was produced by MIX silage, followed consecutively by $6 \mathrm{M}$ silage, $5 \mathrm{M}$ silage, and CON silage both without contamination ( $p<0.001 ; 70.3$ vs. 61.7 vs. 46.3 vs. 33.9 h) and with contamination ( $p<0.001 ; 56.2$ vs. 50.0 vs. 37.5 vs. 27.5 h). In addition, the interaction effect between inoculant application and Fusarium contamination was reported $(p=0.005)$ in the aerobic stability result. Its interaction presented that $6 \mathrm{M}$ silage with contamination had a similar result to $5 \mathrm{M}$ silage without contamination $(50.0$ and $46.3 \mathrm{~h}$ ) and $5 \mathrm{M}$ silage with contamination had a similar result to CON silage without contamination ( 37.5 and $33.9 \mathrm{~h}$ ). 

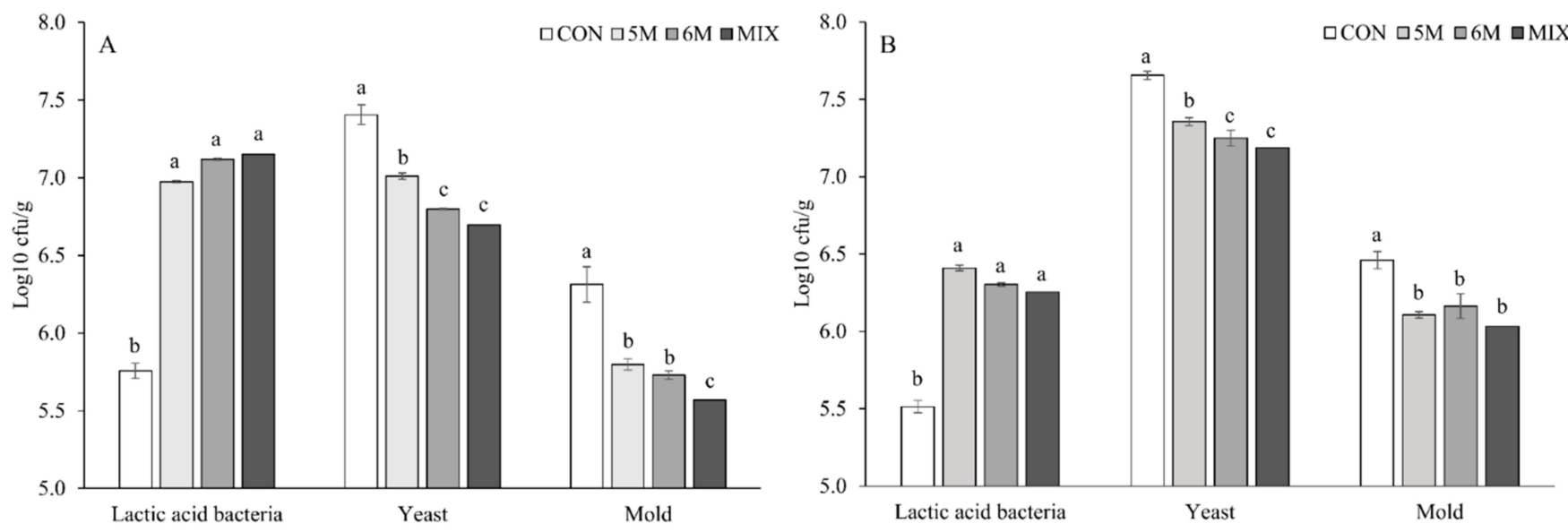

Figure 1. Effects of dual-purpose inoculants on mean count of all microbes from corn silages without (A) or with contamination of Fusarium graminearum (B) during $120 \mathrm{~h}$ of aerobic exposure. The mean count was obtained by generating microbial count data from 0 to $120 \mathrm{~h}$. CON, corn silage applied without inoculant; 5M, corn silage applied with Lactobacillus brevis 5M2; 6M, corn silage applied with Lactobacillus buchneri 6M1; MIX, corn silage applied with the mixture of L. brevis 5M2 and L. buchneri $6 \mathrm{M} 1$ at 1:1 ratio. ${ }^{\mathrm{a}-\mathrm{c}}$ : Means in same microbe with different superscripts differ significantly $(p<0.05)$. Error bar represents standard error.

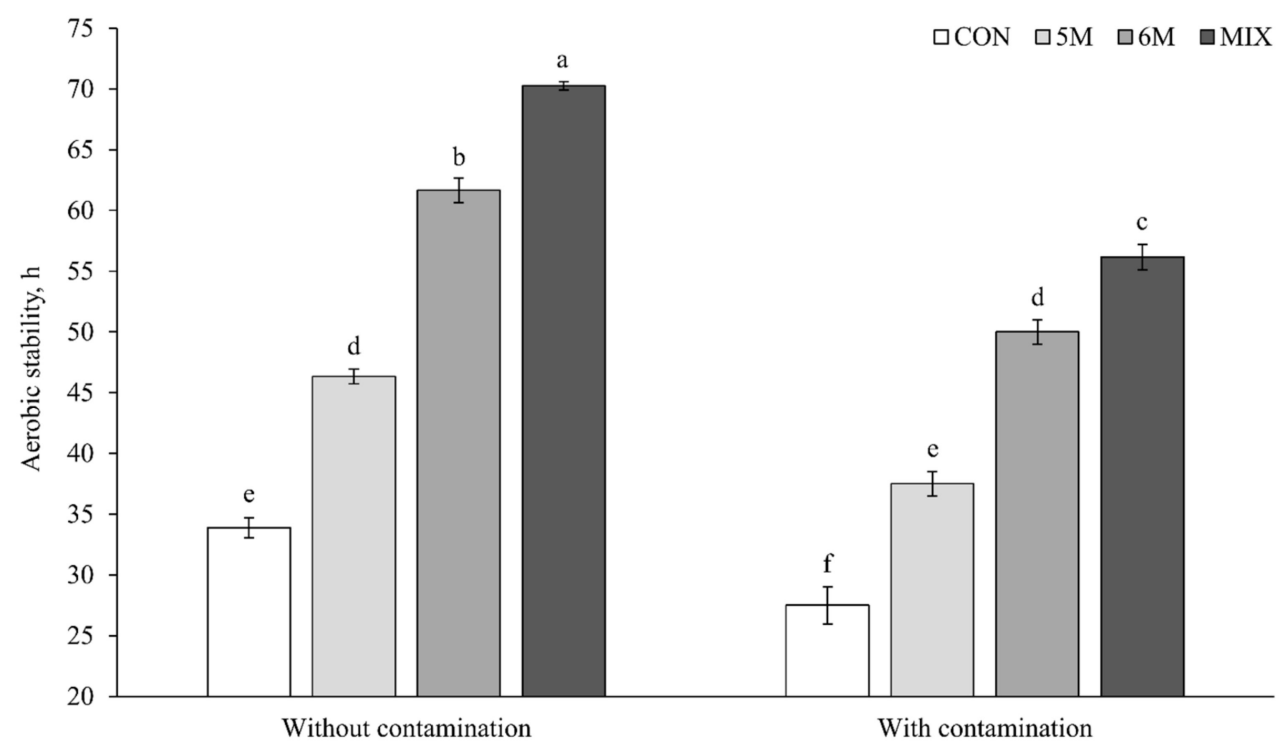

Figure 2. Effects of dual-purpose inoculants on aerobic stability of corn silage. Without contamination, corn silage without Fusarium graminearum contamination at silo open; with contamination, corn silage with F. graminearum contamination at silo open; CON, corn silage applied without inoculant; 5M, corn silage applied with Lactobacillus brevis 5M2; 6M, corn silage applied with Lactobacillus buchneri 6M1; MIX, corn silage applied with the mixture of L. brevis 5M2 and L. buchneri 6M1 at 1:1 ratio. The significant levels of inoculant, Fusarium, and inoculant $\times$ Fusarium are $p<0.001, p<0.001$, and $p=0.05$, respectively. ${ }^{\text {a-f }}$ Means with different superscripts differ significantly $(p<0.05)$. Error bar represent standard error.

\section{Discussion}

\subsection{Chemical Compositions and Fermentation Characteristics}

In the present study, the chemical compositions of Kwangpyeongok corn forage were in a normal range according to Lee et al. [24]. After ensiling, chemical compositions of corn silage were not influenced by inoculant application due to the good acidification in all silages. It could be seen from $\mathrm{pH}$ and ammonia- $\mathrm{N}$ concentration in all silages (Table 3) that they were acidic enough to inhibit nutrient loss and also in a normal range 
according to Kung et al. [2]. Additionally, the concentrations of $\mathrm{CP}$ and EE between before and after ensiling were similar $(p=0.346$ and $p=0.299$, respectively; data were not shown in tables), which could indicate less nutrient loss in all silages due to the good ensiling process. Results of IVDMD and IVNDFD during $48 \mathrm{~h}$ of rumen incubation in the present study supported our previous study, where application of a mixed L. brevis $5 \mathrm{M} 2$ and L. buchneri $6 \mathrm{M} 1$ on farm-scale corn silage could increase nutrient digestibility [16]. Furthermore, corn silage applied single inoculant also presented higher IVDMD and IVNDFD than CON silage that represented activity of carboxylesterase, even though in $6 \mathrm{M}$ silage only increased numerically. According to Adesogan et al. [5] and Ribeiro et al. [29], carboxylesterase could break down the lignocellulose, and then increase the accessibility of the other fibrolytic enzyme in the rumen to degrade cellulose or hemicellulose. Generally, group of carboxylesterases can consist of ferulic acid esterase, acetyl xylan esterase, and $\mathrm{p}$ coumaric esterase [29]. The improvement of IVDMD and IVNDFD by inoculant application in the present study was in agreement with our hypothesis that could help to improve silage quality in the field.

In the fermentation characteristics, all silages with inoculant applications presented lower $\mathrm{pH}$ than $\mathrm{CON}$ silage because they had higher organic acid concentration, such as lactate and acetate [16,30]. An increase of organic acid production in all silages with applied inoculant might be caused by degradation of lignocellulose during ensiling that might provide more soluble carbohydrate. Another reason, an increase of LAB count (Table 3) in all silages with applied inoculants might increase the production of organic acid, and then decrease silage $\mathrm{pH}$ lower than $\mathrm{CON}$ silage $[3,30]$. The ammonia- $\mathrm{N}$ concentration did not differ among treatments that supported the result of $\mathrm{CP}$ concentration after ensiling (Table 2). Ammonia-N concentration in the silage reflects the rate of protein degradation during ensiling [2,30]. With rapid acidification in all silages, undesirable microbes had less chance to degrade the protein content in the silage $[2,30]$. As the heterofermentative LAB, application of L. brevis $5 \mathrm{M} 2$ and L. buchneri $6 \mathrm{M} 1$ could present a lower lactate to acetate ratio on silage, such as in $5 \mathrm{M}$ silage, $6 \mathrm{M}$ silage, and MIX silage. This could have occurred because heterofermentative LAB have the ability to convert lactate into acetate $[3,30]$. Otherwise, $\mathrm{CON}$ silage presented higher lactate to acetate ratio indicating that the fermentation process might be controlled by homofermentative LAB as epiphytic bacteria. In addition, acetate has antifungal activity to inhibit undesirable microbes in the silage [3,31]. The investigation of our previous study found that molds still could grow in the corn silage although they had high lactate concentration and low $\mathrm{pH}$ [31]. It could occur because of the low production of antifungal substance, such as acetate during ensiling [31]. Thus, the presence of antifungal inoculant was necessary for corn silage production. Interestingly, application of a mixed inoculant presented a higher acetate concentration than a single inoculant. According to Santos et al. [32], the use of mixed LAB, such as in the present study, would cause a multi-microbial process during ensiling that combines beneficial effects of each LAB species. Due to its higher beneficial effects, nowadays, many manufacturers produce commercial inoculant containing mixed LAB [32]. On the other opinion, higher acetate concentration in the MIX silage might be caused by the beneficial relation among L. brevis $5 \mathrm{M} 2$ and L. buchneri $6 \mathrm{M} 1$ such as reported by previous study [33]. Nevertheless, Vinderola et al. [33] explained that application of a mixed LAB for inoculant did not always result in beneficial effects for ensiled product, where its effect was dependent on genus or species of LAB. In microbial count, decreased counts of yeast and mold in $5 \mathrm{M}$ silage, $6 \mathrm{M}$ silage, and MIX silage were caused by higher acetate concentration in these silages than in CON silage, which supported the result of previous studies $[3,16,31]$. In the present study, application of all inoculant treatments on corn silage increased LAB count that showed a similar result with Paradhipta et al. [16]. However, other studies reported that application of microbial additives did not always promise to increase LAB count on silage [18,34]. 


\subsection{Rumen Degradation}

Application of a mixture of L. brevis $5 \mathrm{M} 2$ and L. buchneri $6 \mathrm{M} 1$ on corn silage decreased the immediately degradable fraction that is associated with the increase of organic acid concentration such as lactate and acetate. The immediately degradable fraction consists of soluble carbohydrates $[28,35]$ that are used by LAB to produce organic acids during ensiling [30]. Thus, high utilization of soluble carbohydrates to synthesize organic acids during ensiling would decrease concentration of immediately degradable fraction. Supporting the results of IVDMD and IVNDFD, carboxylesterase activity from L. brevis 5M2 and L. buchneri 6M1 improved the total degradable fraction in all silages with applied inoculants, even though in $5 \mathrm{M}$ silage and $6 \mathrm{M}$ silage it only numerically increased. These results were also in agreement with several previous studies that reported an improvement on nutrient digestibility of silage by applying LAB producing ferulic acid esterase [8,36]. The application of these new inoculants could be applied to solve the problem with low digestibility of silage in the field. However, the other studies reported that application of $\mathrm{LAB}$ producing ferulic acid esterase on fermentation of forage did not always increase nutrient digestibility of silages $[18,19]$. In the present study, the carboxylesterase was effective only in MIX silage to increase the potentially degradable fraction and the total degradable fraction. Similar to the result of acetate, beneficial relation between L. brevis $5 \mathrm{M} 2$ and L. buchneri 6M1 might be a reason for these results of degradable fraction.

The improvements of the potentially degradable fraction and the total degradable fraction on MIX silage were also supported with the result of total VFA concentration in the present study, where MIX silage was also the only one that improved total VFA concentration. An increase of the total degradable fraction is associated with an increase of total VFA concentration in the rumen [35]. Furthermore, a decrease of rumen $\mathrm{pH}$ in MIX silage resulted in an increase of VFA concentration that was in agreement with Chesson and Forsberg [35]. Nevertheless, application of a single inoculant on the corn silage also numerically increased total VFA concentration that could contribute to decreasing rumen $\mathrm{pH}$ lower in $5 \mathrm{M}$ silage and $6 \mathrm{M}$ silage than in $\mathrm{CON}$ silage. The higher butyrate concentration in MIX silage was associated with lower propionate concentration, which supported the result of previous studies [35,37]. In addition, the high butyrate concentration in the rumen reflected high degradation of structural carbohydrate. This indicated that application of mixed L. brevis 5M2 and L. bucnheri 6M1 increased the degradation of structural carbohydrate of corn silage that confirmed activity of carboxylesterase.

\subsection{Aerobic Deterioration}

In the present study, contaminating F. graminearum on corn silage at silo open stimulated the growth of mold and yeast that accelerated the decay of silage and decrease of LAB count during feed-out phase. The LAB count was decreased linearly by a longer time of aerobic exposure because the presence of oxygen could inhibit its growth as anaerobic bacteria $[3,30]$. However, inoculant application could extent the growth of LAB count on corn silage both without and with contaminations. This result supported our previous study that inoculation of baled corn silage with a mixed L. brevis 5M2 and L. buchneri 6M1 also extended the growth of LAB during feed-out phase [16]. The L. brevis 5M2 and L. buchneri $6 \mathrm{M} 1$ might have higher aerobic tolerance than epiphytic LAB grown in corn silage.

As aerobic microorganisms, yeast and mold counts were increased linearly by longer time of aerobic exposure due to the presence of oxygen [10,30]. In the present study, longer time of aerobic exposure and Fusarium contamination decreased shelf life of corn silage after silo opening. Both without and with Fusarium contamination, application of all inoculants on corn silage could inhibit the aerobic deterioration at feed-out phase due to the presence of antifungal activity. Previous research also reported a similar result to the present study that application of LAB producing antifungal substances on silages at ensiling inhibited the growth of yeasts and molds after silo opening [7,34]. Generally, the effectiveness of inoculant to inhibit undesirable microbes in the silage could decrease by Fusarium contamination and longer time of aerobic exposure. However, as the result of an interaction 
effect among independent variables (inoculant application, Fusarium contamination, and aerobic hour), MIX silage with contamination inhibited yeasts and molds better than CON silage without contamination until $96 \mathrm{~h}$ of aerobic exposure. Moreover, it presented similar inhibition of yeasts and molds to $6 \mathrm{M}$ silage without contamination. Supporting the result of aerobic stability, application of a mixed inoculant presented greater inhibitions of yeasts and molds than a single inoculant at feed-out phase. It also could be seen that MIX silage presented the lowest mean counts of yeast and mold during $120 \mathrm{~h}$ of aerobic exposure (Figure 2). On the other side, application of F. graminearum on corn silage was reported to increase the yeast growth at feed-out phase. The reason for this result was unclear. As generally known, yeast and mold are classified in the same group as fungi [10,30]. A symbiotic relation between F. graminearum and epiphytic yeast in the corn silage might influence the result of increasing yeast count at feed-out phase in silage with contamination.

The change of microbial counts at feed-out phase influences the aerobic stability of silage [2]. Contamination of F. graminearum decreased the aerobic stability of corn silage in the present study that associated with the increase growths of yeast and mold (Table 4). The results of present study indicated that all inoculants both as single and mixed confirmed antifungal activity by increasing aerobic stability of corn silage both without and with contaminations. Supported by the result of acetate, MIX silage presented the highest aerobic stability, followed by 6M silage and 5M silage. Moreover, MIX silage and 6M silage with F. graminearum contamination still had higher aerobic stability than CON silage without contamination. As the explained before, acetate is one of the antifungal compounds that was reported to increase aerobic stability of silage [3,31]. The result of aerobic stability in the present study supported Kleinschmit et al. [6] and Liu et al. [7] that also reported a similar effect using LAB producing antifungal activity. The result of antifungal activity by LAB in the present study was in agreement with the result of antifungal activity by essential oil $[38,39]$. The application of essential oil on the feed or food could control the growth of pathogenic microorganisms during aerobic condition [38]. Similar with antifungal activity by LAB, the essential oil also generally contains antibacterial and antifungal substances that can inhibit several aerobic microbes including Gram-positive or -negative bacteria and yeast [39].

Almost all of the corn silages ended the aerobic stability when the yeast count was higher than $6.00 \log 10 \mathrm{cfu} / \mathrm{g}$ both without and with contamination. Furthermore, the mold grew massively after aerobic stability was ended in all silages. It could indicate that the increase of silage temperature was initiated by yeast in the present study. Similar to the present study, Kung et al. [2] also explained that aerobic stability of corn silage could be zero if yeast count was more $6.00 \log 10 \mathrm{cfu} / \mathrm{g}$ juts after silo opening. According to Lindgren et al. [40], yeast initiates deterioration and the increase of silage temperature after silo opening. Generally, shelf life of silage in the field decreases along with longer feed-out phase due to the increase of yeast and mold growths. The extended shelf life of corn silage by inoculant application supported our hypothesis that antifungal producing LAB presented a beneficial effect on shelf life of corn silage. In addition, application of these new inoculants could help to improve silage management in the field, especially against the contamination of mold.

\section{Conclusions}

In the present study, application of L. brevis 5M2 and L. buchneri 6M1 as single and mixed inoculant showed beneficial effects on corn silage by improving fermentation characteristics and inhibiting growth of undesirable microbes. In rumen degradation, application of L. brevis 5M2 and L. buchneri 6M1 on corn silage as a mixed inoculant presented better carboxylesterase effects than as a single inoculant to improve degradable fractions and total VFA concentration. Contamination of F. graminearum at feed-out phase increased aerobic deterioration of corn silage, but application of all inoculant treatments presented antifungal effects by extending shelf life of corn silage during feed-out phase. Therefore, the present study concluded that application of mixed L. brevis 5M2 and L. buchneri 6M1 on corn 
silage production is recommended for both activities of antifungal and carboxylesterase by extending shelf life at feed-out phase and improving rumen degradation, respectively.

Author Contributions: Conceptualization, S.C.K. and D.H.V.P.; Methodology, D.H.V.P., H.J.L., Y.H.J., S.S.L. and J.K.; Software, D.H.V.P.; Formal analysis, D.H.V.P.; Validation, D.H.V.P., H.J.L., Y.H.J., S.S.L., H.T.N. and J.S.C.; Supervision, S.C.K.; Data curation, D.H.V.P., H.J.L., Y.H.J. and S.S.L.; Resources, H.G.M.; Writing—original draft preparation, D.H.V.P.; Writing—review and editing, D.H.V.P., J.K. and S.C.K. All authors have read and agreed to the published version of the manuscript.

Funding: This research was supported (Project No. 319039-03-2-HD020) by IPET (Korea Institute of Planning and Evaluation for Technology in Food, Agriculture, Forestry and Fisheries), and Ministry of Agriculture, Food and Rural Affairs, Republic of Korea.

Institutional Review Board Statement: The animal care and procedure to maintain cannulated heifers was approved by animal ethical committee of Gyeongsang National University, Jinju, South Korea (GNU-191011-E0050).

Informed Consent Statement: Not applicable.

Data Availability Statement: Data are available on request from the corresponding author with reasonable reason.

Conflicts of Interest: The authors declare no conflict of interest.

\section{References}

1. Allen, M.S.; Coors, J.G.; Roth, G.W. Corn silage. In Silage Science and Technology; Buxton, D.R., Muck, R.E., Harrison, J.H., Eds.; American Society of Agronomy: Madison, WI, USA, 2003; pp. 547-608. [CrossRef]

2. Kung, L., Jr.; Shaver, R.D.; Grant, R.J.; Schmidt, R.J. Silage review: Interpretation of chemical, microbial, and organoleptic components of silage. J. Dairy Sci. 2018, 101, 4020-4033. [CrossRef] [PubMed]

3. Muck, R.E.; Nadeau, E.M.G.; McAllister, T.A.; Contreras-Govea, F.E.; Santos, M.C.; Kung, L., Jr. Silage review: Recent advances and future uses of silage additives. J. Dairy Sci. 2018, 101, 3980-4000. [CrossRef] [PubMed]

4. Schnürer, J.; Magnusson, J. Antifungal lactic acid bacteria as biopreservatives. Trends Food Sci. Technol. 2005, 16, 70-78. [CrossRef]

5. Adesogan, A.T.; Ma, Z.X.; Romero, J.J.; Arriola, K.G. Ruminant Nutrition Symposium: Improving cell wall digestion and animal performance with fibrolytic enzymes. J. Anim. Sci. 2014, 92, 1317-1330. [CrossRef] [PubMed]

6. Kleinschmit, D.H.; Schmidt, R.J.; Kung, L., Jr. The effects of various antifungal additives on the fermentation and aerobic stability of corn silage. J. Dairy Sci. 2005, 88, 2130-2139. [CrossRef]

7. Liu, Q.; Lindow, S.E.; Zhang, J. Lactobacillus parafarraginis ZH1 producing anti-yeast substance to improve the aerobic stability of silage. Anim. Sci. J. 2018, 89, 1-8. [CrossRef] [PubMed]

8. Nsereko, V.L.; Smiley, B.K.; Rutherford, W.M.; Spielbauer, A.; Forrester, K.J.; Hettinger, G.H.; Harman, E.K.; Harman, B.R. Influence of inoculating forage with lactic acid bacterial strains that produce ferulate esterase on ensilage and ruminal degradation of fiber. Anim. Feed Sci. Technol. 2008, 145, 122-135. [CrossRef]

9. Jin, L.; Duniere, L.; Lynch, J.P.; McAllister, T.A.; Baah, J.; Wang, Y. Impact of ferulic acid esterase producing lactobacilli and fibrinolytic enzymes on conservation characteristics, aerobic stability, and fiber degradability of barley silage. Anim. Feed Sci. Technol. 2015, 207, 62-74. [CrossRef]

10. Ogunade, I.M.; Matinex-Tuppia, C.; Queiroz, O.C.M.; Jiang, Y.; Drouin, P.; Wu, F. Silage review: Mycotoxins in silage: Occurrence, effects, prevention, and mitigation. J. Dairy Sci. 2018, 101, 4034-4059. [CrossRef]

11. Queiroz, O.C.M.; Kim, S.C.; Adesogan, A.T. Effect of treatment with a mixture of bacteria and fibrolytic enzymes on the quality and safety of corn silage infested with different levels of rust. J. Dairy Sci. 2012, 95, 5285-5291. [CrossRef] [PubMed]

12. Keller, L.A.M.; Pereyra, M.L.G.; Keller, K.M.; Alonso, V.A.; Oliveira, A.A.; Almeida, T.X.; Barbosa, T.S.; Nunes, L.M.T.; Cavaglieri, L.R.; Rosa, C.A.R. Fungal and mycotoxins contamination in corn silage: Monitoring risk before and after fermentation. J. Stored Prod. Res. 2013, 52, 42-47. [CrossRef]

13. Queiroz, O.C.M.; Ogunade, I.M.; Weinberg, Z.; Adesogan, A.T. Silage review: Foodborne pathogens in silage and their mitigation by silage additives. J. Dairy Sci. 2018, 101, 4132-4142. [CrossRef]

14. Kim, S.C.; Adesogan, A.T. Influence of ensiling temperature, simulated rainfall, and delayed sealing on fermentation characteristics and aerobic stability of corn silage. J. Dairy Sci. 2006, 89, 3122-3132. [CrossRef]

15. Scudamore, K.A.; Livesey, C.T. Occurrence and significance of mycotoxins in forage crops and silage: A review. J. Sci. Food Agric. 1998, 77, 1-17. [CrossRef]

16. Paradhipta, D.H.V.; Lee, S.S.; Kang, B.; Joo, Y.H.; Lee, H.J.; Lee, Y.; Kim, J.; Kim, S.C. Dual-purpose inoculants and their effects on corn silage. Microorganisms 2020, 8, 765. [CrossRef] [PubMed] 
17. Lee, J.; Kim, H.; Jeon, J.J.; Kim, H.S.; Zeller, K.A.; Carter, L.L.A.; Leslie, J.F.; Lee, Y.W. Population structure of and mycotoxin production by Fusarium graminearum from maize in South Korea. J. Appl. Environ. Microbiol. 2012, 78, 2161-2167. [CrossRef] [PubMed]

18. Kang, T.W.; Adesogan, A.T.; Kim, S.C.; Lee, S.S. Effects of an esterase-producing inoculant on fermentation, aerobic stability, and neutral detergent fiber digestibility of corn silage. J. Dairy Sci. 2009, 92, 732-738. [CrossRef]

19. Lynch, J.P.; Lin, L.; Lara, E.C.; Baah, J.; Beauchemin, K.A. The effect of exogenous fibrinolytic enzymes and a ferulic acid esterase-producing inoculant on the fiber degradability, chemical composition and conservation characteristics of alfalfa silage. Anim. Feed Sci. Technol. 2014, 193, 21-31. [CrossRef]

20. Arriola, K.G.; Kim, S.C.; Huisden, C.M.; Adesogan, A.T. Stay-green ranking and maturity of corn hybrids: 1 . Effects on dry matter yield, nutritional value, fermentation characteristics, and aerobic stability of silage hybrids in Florida. J. Dairy Sci. 2012, 95, 964-974. [CrossRef]

21. Association of Official Analytical Chemists. Official Methods of Analysis, 18th ed.; AOAC International: Washington, DC, USA, 2005.

22. Tilley, J.M.A.; Terry, R.A. A two-stage technique for the in vitro digestion of forage crops. J. Br. Grassl. Soc. 1963, 18, 104-111. [CrossRef]

23. Chaney, A.L.; Marbach, E.P. Modified reagents for determination of urea and ammonia. Clin. Chem. 1962, 8, 130-132. [CrossRef]

24. Lee, S.S.; Lee, H.J.; Paradhipta, D.H.V.; Joo, Y.H.; Kim, S.B.; Kim, D.H.; Kim, S.C. Temperature and microbial changes of corn silage during aerobic exposure. Asian-Australas. J. Anim. Sci. 2019, 32, 988-995. [CrossRef]

25. Muck, R.E.; Dickerson, J.T. Storage temperature effects on proteolysis in alfalfa silage. Trans. ASASE 1988, 31, 1005-1009. [CrossRef]

26. Adesogan, A.T.; Krueger, N.K.; Kim, S.C. A novel, wireless, automated system for measuring fermentation gas production kinetics of feeds and its application to feed characterization. Anim. Feed Sci. Technol. 2005, 123-124, 211-223. [CrossRef]

27. SAS Institute Inc. SAS/STAT User's Guide, Version 9; SAS Institute Inc.: Cary, NC, USA, 2002.

28. McDonald, I. A revised model for the estimation of protein degradability in the rumen. J. Agric. Sci. 1981, 96, 251-252. [CrossRef]

29. Ribeiro, G.O.; Gruninger, R.J.; Badhan, A.; McAllister, T.A. Mining the rumen for fibrolytic feed enzymes. Anim. Front. 2016, 6, 20-26. [CrossRef]

30. McDonald, P.; Henderson, A.R.; Heron, S.J.E. The Biochemistry of Silage, 2nd ed.; Chalcombe Publ.: Marlow, UK, $1991 ;$ pp. 48-291.

31. Danner, H.; Holzer, M.; Mayrhuber, E.; Braun, R. Acetic acid increases stability of silage under aerobic conditions. Appl. Environ. Microbiol. 2003, 69, 562-567. [CrossRef] [PubMed]

32. Santos, M.S.; Nogueira, M.A.; Hungria, M. Microbial inoculants: Reviewing the past, discussing the present and previewing an outstanding future for the use of beneficial bacteria in agriculture. AMB Express 2019, 9, 205. [CrossRef] [PubMed]

33. Vinderola, C.G.; Mocchiutti, P.; Reinheimer, J.A. Interactions among lactic acid starter and probiotic bacteria used for fermented dairy products. J. Dairy Sci. 2002, 85, 721-729. [CrossRef]

34. Paradhipta, D.H.V.; Joo, Y.H.; Lee, H.J.; Lee, S.S.; Kim, D.H.; Kim, J.D.; Kim, S.C. Effects of inoculant application on fermentation quality and rumen digestibility of high moisture sorghum-sudangrass silage. J. Appl. Anim. Res. 2019, 47, 486-491. [CrossRef]

35. Chesson, A.; Forsberg, C.W. Polysaccharide degradation by rumen microorganisms. In The Rumen Microbial Ecosystem, 2nd ed.; Hobson, P.N., Stewart, C.S., Eds.; Blackie Academic and Professional: London, UK, 1997; pp. 329-381. [CrossRef]

36. Paradhipta, D.H.V.; Joo, Y.H.; Lee, H.J.; Lee, S.S.; Kwak, Y.S.; Han, O.K.; Kim, D.H.; Kim, S.C. Effects of wild or mutated inoculant on rye silage and its rumen fermentation indices. Asian-Australas. J. Anim. Sci. 2020, 33, 949-956. [CrossRef] [PubMed]

37. Sutton, J.D.; Dhanoa, M.S.; Morant, S.V.; France, J.; Napper, D.J.; Schuller, E. Rates of production of acetate, propionate, and butyrate in the rumen of lactating dairy cows given normal and low-roughage diets. J. Dairy Sci. 2003, 86, 3620-3633. [CrossRef]

38. Rossi, C.; Chaves-López, C.; Serio, A.; Casaccia, M.; Maggio, F.; Paparella, A. Effectiveness and mechanisms of essential oils for biofilm control on food-contact surfaces: An update review. Crit. Rev. Food Sci. Nutr. 2020, 1-20. [CrossRef] [PubMed]

39. Donadu, M.G.; Le, N.T.; Ho, D.V.; Doan, T.Q.; Le, A.T.; Raal, A.; Usai, M.; Marchetti, M.; Sanna, G.; Madeddu, S.; et al. Phytochemical compositions and biological activities of essential oil from the leaves, rhizomes, and whole plant of Hornstedtia bella Škorničk. Antibiotics 2020, 8, 334. [CrossRef] [PubMed]

40. Lindgren, S.; Pettersson, K.; Kaspersson, A.; Jonsson, A.; Lingvall, P. Microbial dynamic during aerobic deterioration of silage. J. Sci. Food Agric. 1985, 36, 765-774. [CrossRef] 